\title{
A Study on the Variations of Size, Shape and External Features of the Spleen in South Indian Population
}

\author{
Estudio sobre la Variación del Tamaño, Forma y Características \\ Externas del Bazo en la Población del Sur de la India
}

"Satheesha Nayak B.; "S. N. Somayaji \& "Soumya K. V.

NAYAK, B. S.; SOMAYAJI, S. N. \& SOUMYA, K. V. A Study on the variations of size, shape and external features of the spleen in South Indian population. Int. J. Morphol., 29(3):675-677, 2011.

SUMMARY: The spleen is the largest lymphoid organ. It is wedge shaped and measures about 1 inch thick, 3 inches broad and 5 inches long. It presents characteristic notches on its superior margin and has a hilum on the visceral surface. The aim was to study the anomalies related to size, shape and external features of the spleen and discuss their clinical importance. As there are not many reports on variations in size shape and features of spleen in the South Indian population, we decided to do this study on cadaveric specimens. We observed 50 spleens fixed with 10\% formalin. Among the 50 spleens observed, 25 spleens (50\%) were normal and had all the features explained in the textbooks. 25 spleens (50\%) did not have any notches on the superior margin, 2 spleens (4\%) did not have a hilum and 4 spleens (8\%) were small sized i.e. about 3 inches long. One of the spleens (2\%) was "liver shaped" with 2 lobes. The knowledge of external features and dimensions of spleen are important for radiologists and surgeons as it may lead to confusions in interpreting radiographs and in the procedures of ultrasound examinations.

KEY WORDS: Spleen; Anomaly; Variation; Splenic notch; Anatomy.

\section{INTRODUCTION}

The spleen is the largest lymphoid organ in the body. It is situated in the left hypochondriac region. It is wedge shaped and has two ends i.e. anterior and posterior, two surfaces i.e. diaphragmatic and visceral, and three margins i.e. superior, inferior and intermediate. The superior margin of the spleen possesses characteristic notches. The normal adult human spleen is about 1 inch thick, 3 inches broad, 5 inches long and 7 ounces in weight. The normal spleen is not palpable. The knowledge of anomalous size, shape or external features may be of importance to surgeons and radiologists. We studied 50 stored spleens for their variations.

\section{MATERIAL AND METHOD}

At Melaka Manipal Medical College (Manipal Campus) Manipal, the formalin embalmed cadavers are stored in a cold room. After the routine dissections for undergraduate medical students, various organs are stored in stainless steel tanks containing $10 \%$ formalin. We studied 50 spleens in store since past 5 years. The cadavers are from the Southern part of India. During the study, the length breadth and thickness were observed. The organ was also observed for its abnormal shape and presence of notches on its superior margin. The anomalies were photographed.

\section{RESULTS}

Among the 50 spleens observed, 25 spleens (50\%) were normal and had all the features explained in the textbooks (Fig. 1). Twenty five spleens (50\%) did not have any notches (Fig. 3). 2 spleens (4\%) did not have a hilum (Fig. 3) and 4 spleens (8\%) were small sized i.e. about 3 inches long (Fig. 4). One of the 50 spleens (2\%) was liver shaped with 2 lobes (Fig. 2). In the spleens without hilum, the splenic vessels entered the spleen by piercing the visceral surface at different places (Fig. 3).

\footnotetext{
* Department of Anatomy, Melaka Manipal Medical College (Manipal Campus) Manipal University, India.

** Manipal Institute of Technology, Manipal University, India.
} 


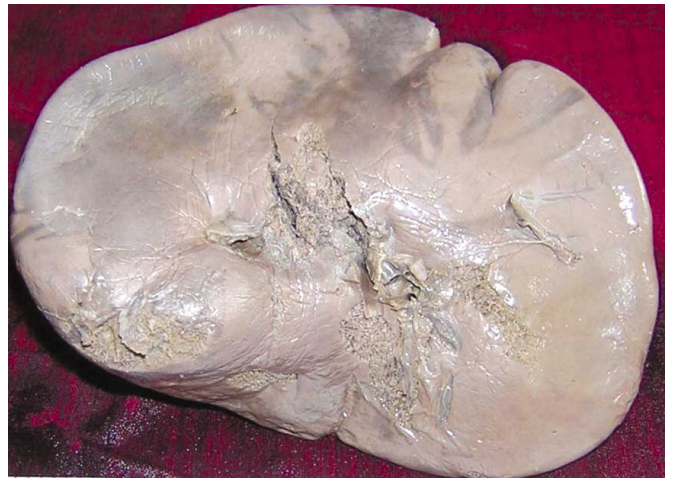

Fig. 1. Visceral surface of the normal spleen.

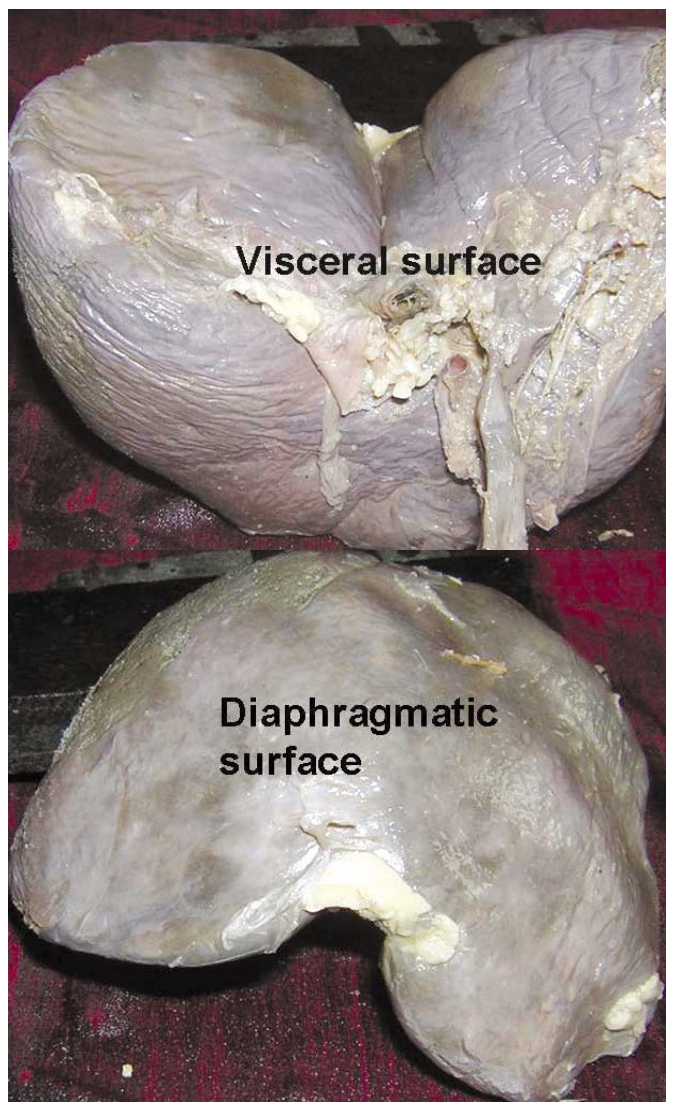

Fig. 2. Visceral and diaphragmatic surfaces of "liver shaped spleen".

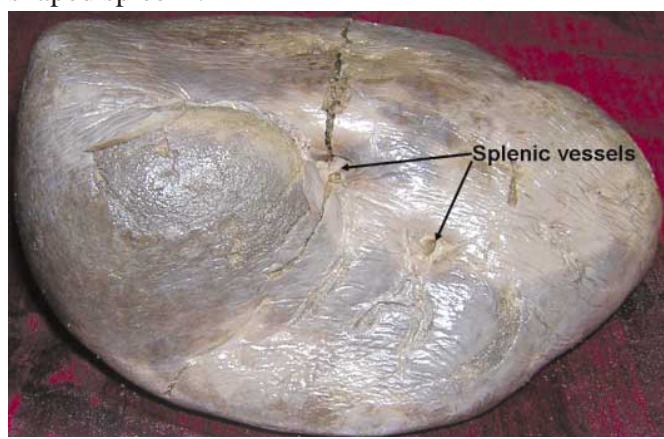

Fig. 3. Visceral surface of a spleen without hilum and splenic notches.

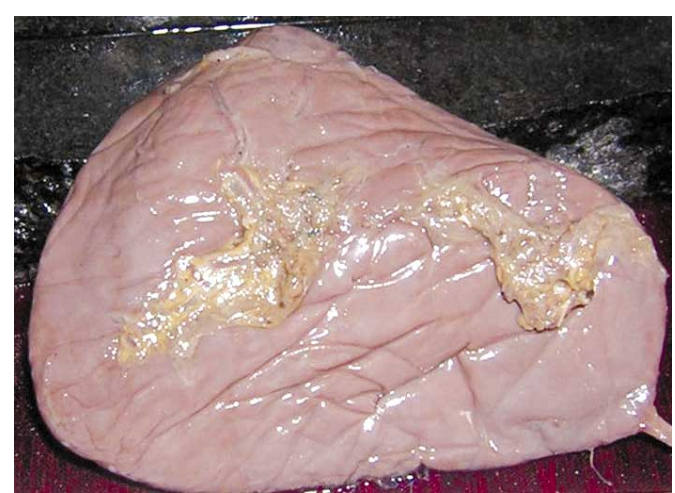

Fig. 4. Visceral surface of an abnormally small spleen.

\section{DISCUSSION}

The spleen develops from the coelomic epithelium of the cranial part of the dorsal mesogastrium in the sixth week of intra-uterine life (Sadler, 2000; Standring, 2005). During the early development, the spleen is represented by a few splenic nodules which eventually fuse to form the spleen. Some of these nodules may develop independently. This will lead to formation of accessory spleens. The embryological reason for having notches on the superior margin is the improper fusion of the splenic nodules along the superior margin during development. Until recently, the spleen was considered to be a less significant organ (Jakubovsky \& Porubsk $\$, 1995$ ) but now it is known to be important in circulatory and immune systems.

One of the most common congenital anomalies of the spleen is the presence of accessory spleens in various parts of the abdomen in addition to the main organ (Gayer et al., 2006). The accessory spleens are seen in about $10-15 \%$ of individuals, out of which $1-2 \%$ may be located in the tail of the pancreas (Weiand \& Mangold, 2003). Presence of retroperitoneal accessory spleens may mimic retroperitoneal tumors with the history of epigastric pain, intermittent nausea and vomiting (Souparis et al., 2002).

In the current study, only $50 \%$ of the spleens presented with a notched superior margin. The presence of the notches on the superior margin is useful for the physician to palpate the spleen when it is enlarged. In the previous studies the splenic notches on the superior margin were seen in 78.6\% (Skandalakis et al., 1993), 70\% (Soyluolu et al., 1996), 95\% (Ungör et al., 2007) and 98\% (Das et al., 2008) of cases respectively. We saw splenic notches only in 50\% of cases and this is the lowest percentage reported so far.

The spleen usually presents a hilum on the visceral surface and the hilum is not covered by the peritoneum. Of the spleens studied $4 \%$ did not have a classic hilum, instead the blood vessels randomly pierced the visceral surface. Such cases have not been reported yet. We also saw a unique "liver shaped" spleen which had two lobes. A case of such spleen has not been reported hitherto. Extremely small sized spleens 
and bilobed spleens as reported in our study may cause confusions in ultrasound and scanning examinations as the dimensions of liver spleen and kidney are important for such clinical examinations (Safak et al., 2005).

NAYAK, B. S.; SOMAYAJI, S. N. \& SOUMYA, K. V. Estudio sobre la variación del tamaño, forma y características externas del bazo en la población del Sur de la India. Int. J. Morphol., 29(3):675-677, 2011.

RESUMEN: El bazo es el mayor órgano linfoide. Tiene forma de cuña y mide alrededor de 2,5 $\mathrm{cm}$ de espesor, 7,5 $\mathrm{cm}$ de ancho y 12,5 cm de largo. Presenta incisuras características en su margen superior y tiene un hilio en la superficie visceral. Debido a que no existen muchos informes sobre las variaciones del bazo en la población del sur de la India, el objetivo de esta investigación fue estudiar dichas variaciones y discutir su importancia clínica. Se observaron 50 bazos fijados con formalina al $10 \%$. 25 bazos (50\%) fueron normales y tenían las características que se explican en los libros anatómicos. 25 bazos (50\%) no tenían ninguna incisura en el margen superior, 2 bazos (4\%) no tenían hilio y 4 bazos ( $8 \%$ ) eran de tamaño pequeño, con alrededor de 7,2 cm de largo. Uno de los bazos (2\%) tenía "forma de hígado" con dos lóbulos. El conocimiento de las características externas y las dimensiones del bazo son importantes para los radiólogos y cirujanos, ya que pueden dar lugar a confusiones en la interpretación de radiografías y en los procedimientos de examen ultrasonográfico.

PALABRAS CLAVE: Bazo; Anomalía; Variación; Incisura esplénica; Anatomía.

\section{REFERENCES}

Das, S.; Abd Latiff, A.; Suhaimi, F. H.; Ghazalli, H. \& Othman, F. Anomalous splenic notches: a cadaveric study with clinical importance. Bratisl. Lek. Listy, 109(11):513-6, 2008.

Gayer, G.; Hertz, M.; Strauss, S. \& Zissin, R. Congenital anomalies of the spleen. Semin. Ultrasound CT MR, 27(5):358-69, 2006.

Jakubovsk $\ddagger$ J. \& Porubsk $\ddagger$ J. Functional morphology of the spleen. Bratisl. Lek. Listy, 96(12):637-41, 1995.

Sadler, T. W. Langman's Medical Embryology. Baltimore, Lippincott Williams \& Wilkins, 2000. p.277.

Safak, A. A.; Simsek, E. \& Bahcebasi, T. Sonographic assessment of the normal limits and percentile curves of liver, spleen, and kidney dimensions in healthy schoolaged children. J. Ultrasound Med., 24(10):1359-64, 2005 .

Skandalakis, P. N.; Colborn, G. L.; Skandalakis, L. J.; Richardson, D. D.; Mitchell, W. E. Jr. \& Skandalakis, J. E. The surgical anatomy of the spleen. Surg. Clin. North. Am., 73(4):747-68, 1993.

Souparis, A.; Papaziogas, B.; Alexandrakis, A.; Koutelidakis, J.; Paraskevas, G. \& Papaziogas, T. An unusual case of retroperitoneal accessory spleen with vascular supply directly from the aorta. Minerva Chir., 57(4):513-5, 2002.
Soyluolu, A. ; Tanyeli, E.; Marur, T.; Ertem, A. D.; Özku, K. \& Akkn, S. M. Splenic artery and relation between the tail of the pancreas and spleen in a surgical anatomical view. Karadeniz Tıp Dergisi, 9:103-7, 1996.

Standring, S. Gray's Anatomy. The Anatomical Basis of Clinical Practice. New York, Elsevier Churchill Livingstone, 2005. pp.1239-44.

Ungör, B.; Malas, M. A.; Sulak, O. \& Albay, S. Development of spleen during the fetal period. Surg. Radiol. Anat., 29(7):543-50, 2007.

Weiand, G. \& Mangold, G. Accessory spleen in the pancreatic tail -- a neglected entity? A contribution to embryology, topography and pathology of ectopic splenic tissue. Chirurg., 74(12):1170-7, 2003.

Correspondence to:

Satheesha Nayak B.

Professor and Head of the Department of Anatomy Melaka Manipal Medical College (Manipal Campus) International Centre for Health Sciences Madhav Nagar, Manipal, Udupi District Karnataka State INDIA.

Email: nayaksathish@yahoo.com

Received: 19-11-2010

Accepted: 22-05-2011 